\title{
Characteristic of thermochemical parameters of aboveground parts of selected sedges (Carex L. Cyperaceae)
}

\author{
Bogusława Waliszewska ${ }^{1}$, Magdalena Janyszek ${ }^{2}$, Mieczysław Grzelak ${ }^{3}$, \\ Eliza Gawer ${ }^{4}$ \\ ${ }^{\text {I }(I n s t i t u t e ~ o f ~ C h e m i c a l ~ W o o d ~ T e c h n o l o g y, ~ P o z n a n ~ U n i v e r s i t y ~ o f ~ L i f e ~ S c i e n c e s, ~ P o l a n d) ~}$ \\ 2 (Department of Botany, Poznan University of Life Sciences, Poland) \\ ${ }^{3}$ (Department of Grassland and Natural Landscape Sciences, Poznan University of Life Sciences, Poland), \\ ${ }^{4}$ ('Department of Forage Crop Production, Institute of Soil Science and Plant Cultivation-State Research \\ Institute, Poland)
}

\begin{abstract}
Sedges (Carex, Cyperaceae), among others, due to the similarity of the form of growth as well as morphological similarity to grasses fulfil many requirements expected from energetic raw materials. The main purpose of the performed experiments was: to analyse the chemical composition of over ground parts representing 9 sedge species, determine their heat of combustion and calorific value and, last but not least, to determine if and which of the examined sedge species can be treated as a potential source of energy. The investigation showed that only C. riparia was characterised by a low (17790 J/g) heat of combustion. The remaining species exhibited combustion heats ranging from $18750 \mathrm{~J} / \mathrm{g}$ to $19740 \mathrm{~J} / \mathrm{g}$. The calorific value of all species - with the exception of C. riparia - was fairly similar and ranged from $17310 \mathrm{~kJ} / \mathrm{kg}$ to $18010 \mathrm{~kJ} / \mathrm{kg}$. The highest calorific value $(18010 \mathrm{~kJ} / \mathrm{kg})$ was determined in C. acutiformis, while the lowest - in C. riparia (16 $040 \mathrm{~kJ} / \mathrm{kg}$ ). The obtained research results confirmed that sedge swards can be treated as energetic raw material.
\end{abstract}

Keywords: Carex, energy value, chemical composition, combustion

\section{INTRODUCTION}

Sedges (Carex L., Cyperaceae) constitute a group of herbaceous plants widely distributed throughout most of the world. This genus comprises over 2000 species [1] occasionally found on a mass scale and growing in many different plant communities, in inundation (e.g Carex riparia Curt., C. paniculata L.), wet (e.g. C. remota L., C. elata All.) and arid areas (e.g. C. arenaria L.). Sedges as a genus exhibit an extensive spectrum of habitat requirements. They constitute a significant component of many plant communities, frequently serving the role of dominant species and occasionally forming large, single-species patches. This is particularly evident in case of representatives of tall species, frequently characterized by a considerable increment in biomass within one vegetation season, as it is the case with e.g. C. riparia, C. paniculata, C. acuta L. or C. remota. Many of these species, apart from rapid growth of vegetative parts, related with the above mentioned increment in biomass, exhibit also other properties, such as e.g. an extensive tolerance towards habitat requirements, including soil. At the same time, they are renewable materials and in case of many species - found extensively in the wild.

Sedges serve an essential role in various ecosystems, among other things due to their share in their biomass, not only as living components of phytocenoses, but also as crucial components of organic deposits in various types of peatbogs. It is estimated that the share of representatives of the genus Carex in peat deposits may be as high as approx. 45\% [2]. Presently we may observe an increased demand for energy, potentially threatening depletion of reserves or availability of conventional energy sources. Thus the European Union predicts that by the year 2020 the share of renewable energy will be increased to $20 \%$. For this reason it is estimated that as a consequence it will be biomass which will constitute the most important source of energy, particularly essential in comparison to conventional sources, since it is renewable.

Thus not only in Europe, but practically worldwide renewable energy sources are being searched for both among plants and inanimate components of the natural environment, constituting renewable energy sources, including peat deposits [2].

Energy plants comprise a group of species characterised by high increments of biomass over relatively short time periods, high calorific value, slight soil requirements and high resistance to diseases and pests. Shrubs and trees are frequently used for this purpose, e.g. different willow (Salix) species and Rosa multiflora Thum., while it is also proposed to use poplar Populus and horse chestnut Aesculus hippocastanum L. [3]. The group of energy plants comprises also herbaceous plants. The most popular of these include e.g. Sida hermaphrodita (L.) Rusby, Helianthus tuberosus L., Polygonum sachalinense F. Schmidt, Miscanthus sinensis Anderss. Miscanthus x giganteus, Miscanthus sacchariflorus Maxim., Sida hermaphrodita and Spartina pectinata Link. [4]. Recently considerable popularity is observed for pellets, both produced from a single-species plant material such as e.g. 
Miscanthus, wheat straw or reed (Phragmites sp.), and from the entire harvest of various types of meadows, comprising many plant species. It is sometimes believed that in view of the climatic conditions of Central Europe one of the most advantageous solutions would be provided by utilisation of straw and grass biomass for energy [5].

Certain sedge species meet many requirements posed for energy resources and due to the morphological similarity of their vegetative organs to those of grasses they may be identically processed. Additionally, in the last decade we have been observing considerable interest in this respect both in sedges as biomass of their aboveground parts and in peatbogs as habitats connected with those plants. Particular attention has been focused on sedges as reservoirs of organic deposits formed among other things from aboveground and underground shoots of sedges [6,7]. However, we need to take into consideration the fact that theoretically, e.g. in terms of profitability, the use of a given plant material as an energy resource is viable when available energy contained in plant biomass evidently exceeds the amount of energy required for its cultivation and harvesting.

The aim of this study was to analyse the chemical composition of aboveground parts in representatives of 9 selected sedge species and to determine their gross calorific value and calorific value, as well as evaluate on the basis of recorded results - whether any and if so, which of the tested sedge species may be potentially used as an energy source.

\section{MATERIAL AND Methods}

A total of 9 sedge species (Carex), commonly found in Central Europe and growing in diverse habitats and in different plant communities, were selected for analyses within this study. The species composition of the analysed group was selected in view of the following parameters: frequency and abundance of occurrence (all analysed species); availability on site (all analysed species); large dimensions of individual plants (runner species) or clusters (cluster species); large amounts of biomass produced within a single vegetation species $(C$. elongata, C. acutiformis, C. disticha, C. paniculata, C. riparia); a trend for the formation of single-species patches in plant communities (C. praecox, C. pilulifera, C. brizoides, C. flava, C. riparia) and duration of plants in the autumn-winter season (C. paniculata, C. riparia).

Selected species represented different habitat types from inundation areas as e.g. C. riparia, through wet areas for e.g. C. brizoides, up to arid areas as e.g. C. pilulifera.

A characteristic trait of plant materials is connected with the heterogeneity of their anatomical structure and frequently rather considerable differences in the chemical composition of plants even within a single species. It depends on many factors, e.g. age, site and even a given part of the plant. All these factors influence further industrial utilisation of the raw material. For this reason plants from natural localities and plant communities characteristic of a given species were selected for analyses.

Harvests were performed in the first half of October. Analyses were conducted on aboveground parts of plants devoid of runners. In the autumn they are practically leaves with single stems free of fruits. After harvest the plant material was conditioned in a climatic chamber at a temperature of $20^{\circ} \mathrm{C}$ until constant moisture content. In the further stage of preparation for analyses the material was preliminarily comminuted manually and next it was ground in a Fritsch type 15 laboratory knife mill. For the purpose of chemical analyses the analytical fraction of $0.5-1.0 \mathrm{~mm}$ grain size was separated using sieves. Analyses of gross calorific value were conducted on a finer fraction, i.e. dust with grain size of up to $0.1 \mathrm{~mm}$.

Analyses of chemical composition of the raw material were performed according to the PN-92/P-50092 standard for plant material and the following parameters were determined:

- moisture content using the over-dry (gravimetric) method;

- content of cellulose according to Seifert using a mixture of acetylacetone and dioxane;

- content of lignin according to Tappi using concentrated sulfuric acid;

- content of holocellulose using sodium chlorite;

- amount of substances soluble in organic solvents according to Soxhlet.

Contents of minerals were determined according to the DIN 51731 standards.

Results are means of three measurements and were calculated in relation to dry matter of the material.

Gross calorific value was determined according to the PN-81/G-04513 standard in a ZKL-4 calorimeter for measurements of gross calorific value $\left(\mathrm{Q}_{\mathrm{s}}^{\mathrm{a}}\right)$ of solid fuels. Analytical samples of $1 \mathrm{~g}$ material were completely combusted in the atmosphere of oxygen at $3 \mathrm{MPa}$.

In order to provide a more comprehensive characteristic of the material its calorific value was also calculated, i.e. gross calorific value less heat of evaporation emitted from the fuel in the course of its combustion.

\section{RESULTS}

Content of the primary building component, i.e. cellulose, in aboveground parts of the analysed sedge species fell within a wide range from $30.1 \%$ to $46.2 \%$. The highest content was recorded in the material from $C$. 
riparia, while it was lowest in C. praecox. Large amounts of cellulose were found in C. flava and C. pilulifera, in which $40.6 \%$ and $39.5 \%$ this component were detected. In turn, a relatively low cellulose content of $35.7 \%$ was recorded in $C$. disticha. The other analysed sedge species were characterised by similar contents of cellulose ranging from $36.9 \%$ to $38.4 \%$ (TABLE 1 ).

TABLE 1. Chemical composition of above ground parts of studied sedges.

\begin{tabular}{|c|c|c|c|c|c|}
\hline Species & $\begin{array}{cc}\text { Humidity } & \mathrm{W} \\
{[\%]} & \end{array}$ & $\begin{array}{c}\text { Substances } \\
\text { extracted }[\%]\end{array}$ & cellulose [\%] & lignin $[\%]$ & $\begin{array}{c}\text { Holocellulose } \\
{[\%]}\end{array}$ \\
\hline 1 C. praecox & 8,1 & 23,13 & 30,1 & 11,9 & 48,2 \\
\hline 2 C. elongata & 8,6 & 13,93 & 36,9 & 18,7 & 56,3 \\
\hline 3 C. acutiformis & 7,6 & 12,72 & 37,4 & 20,3 & 54,6 \\
\hline 4 C. pilulifera & 8,2 & 21,89 & 39,5 & 18,4 & 54,0 \\
\hline 5 C. brizoides & 8,0 & 14,03 & 36,9 & 17,9 & 57,3 \\
\hline 6 C. disticha & 9,4 & 13,60 & 35,7 & 19,1 & 50,5 \\
\hline 7 C. flava & 8,4 & 17,66 & 40,6 & 15,7 & 65,4 \\
\hline 8 C. paniculata & 9,2 & 8,31 & 38,4 & 20,8 & 55,2 \\
\hline 9 C. riparia & 9,7 & 8,07 & 46,2 & 28,1 & 56,0 \\
\hline
\end{tabular}

When analysing lignin content in the tested material discrepancies between species were found in its contents, amounting to as much as over $16 \%$. The greatest content of lignin, i.e. $28.1 \%$, was reported for $C$. riparia, while the lowest, as little as $11.9 \%$, in C. praecox. A slight amount of $15.7 \%$ lignin was contained in $C$. flava, whereas in C. brizoides, C. pilulifera and C. elongata similar amounts were detected, ranging from $17.9 \%$ to $18.7 \%$ lignin. Carex disticha contained $19.1 \%$ this component, while two species, i.e. C. paniculata and $C$. acutiformis, contained $20.8 \%$ and $20.3 \%$ lignin, respectively (TABLE 1).

Similarly as in the analysis of the basic building components of plant materials, also in case of holocellulose content in the analysed species considerable discrepancies, up to over $17 \%$, were observed in its contents. The highest amount, i.e. $65.4 \%$ holocellulose, was recorded for $C$. flava, while the lowest $(48.2 \%)$ was found in $C$. praecox. Relatively low amounts were observed in $C$. disticha $(50.5 \%)$. The other investigated species contained similar amounts of these compounds, ranging from $54.0 \%$ to $57.3 \%$ (TABLE 1).

Very high levels as well as an extensive range of values from $8.07 \%$ to $23.13 \%$ were observed for the amounts of substances extracted with alcohol. Their lowest amounts were contained in C. riparia and $C$. paniculata, in which $8.07 \%$ and $8.31 \%$ compounds eluted with alcohol were detected. A similar level of these substances, from $12.72 \%$ to $14.03 \%$, was recorded in C. acutiformis, C. disticha, C. elongata and C. brizoides. Carex flava contained $17.66 \%$ extraction substances, while in C. pilulifera it was as much as $21.89 \%$ (TABLE 1 ).

Contents of minerals in the tested species are presented in Table 2. All the analysed sedge species contained large amounts of ash, ranging from $4.2 \%$ to $12.3 \%$. The greatest level of this component was contained in C. riparia, while the lowest - in C. flava. Rather high amounts of ash, amounting to $7.3 \%$, were detected in $C$. disticha. The other tested species were characterised by similar amounts of minerals, ranging from $4.9 \%$ to $6.7 \%$, respectively.

TABLE 2. Mineral substances, heat of combustion and calorific value of above ground parts of studied sedges.

\begin{tabular}{|l|c|c|c|}
\hline \multicolumn{1}{|c|}{ Species } & Mineral substances [\%] & Heat of combustion [J/g] & Calorific value [kJ/kg] \\
\hline 1 C. praecox & 6,5 & 19430 & 17690 \\
\hline 2 C. elongata & 6,2 & 19040 & 17310 \\
\hline 3 C. acutiformis & 4,9 & 19740 & 18010 \\
\hline 4 C. pilulifera & 6,7 & 18750 & 17030 \\
\hline 5 C. brizoides & 5,7 & 19640 & 17930 \\
\hline 6 C. disticha & 7,3 & 19000 & 17280 \\
\hline 7 C. flava & 4,2 & 19450 & 17760 \\
\hline 8 C. paniculata & 5,2 & 19110 & 17370 \\
\hline 9 C. riparia & 12.3 & 17790 & 16040 \\
\hline
\end{tabular}

When analysing gross calorific value for the tested sedge species it may be stated that only C. riparia was characterised by its low value, amounting to as little as $17790 \mathrm{~J} / \mathrm{g}$. The other species had relatively high gross calorific values between $18750 \mathrm{~J} / \mathrm{g}$ and $19740 \mathrm{~J} / \mathrm{g}$. Also calorific value, i.e. gross calorific value less heat of evaporation of water emitted during combustion, except for C. riparia fell within a similar level from 17310 $\mathrm{kJ} / \mathrm{kg}$ to $18010 \mathrm{~kJ} / \mathrm{kg}$. Carex riparia had the lowest calorific value of $16040 \mathrm{~kJ} / \mathrm{kg}$, while C. acutiformis - the highest, amounting to $18010 \mathrm{~kJ} / \mathrm{kg}$ (TABLE 2). 


\section{DISCUSSION}

A plant material for energy use has to meet specific thermal requirements. In the evaluation of its quality the most frequent parameters taken into consideration include calorific value and moisture content. In turn, the most important thermophysical parameters are calorific value and gross calorific value. Analysis of results for the tested materials shows that all the investigated species, except for C. riparia, are characterised by comparable gross calorific values and calorific values.

Cellulose, together with hemicelluloses, serves the role of skeleton components and its fibrous structure provides cells with considerable mechanical strength. Cellulose content in plants falls within a wide range of values and depends e.g. on the age of plants, habitat conditions and even parts of plants $[8,9,10,11]$. Annual plants contain approx. $20-40 \%$ cellulose. Among natural products the greatest amounts of pure cellulose are contained in cotton (95-98\%), ramie (approx. 76\%), flax (approx. 71\%), jute (approx. 71\%), wood (approx. $45 \%$ ) and straw (approx. 40\%). In the investigated group of sedges the highest content of cellulose was found in C. riparia (46.2\%). It falls within a similar range to that of woody plants and it is comparable to that found e.g. in wood of common osier Salix viminalis Kortur (UWM 144) (45.97\%) or S. viminalis x S. purpurea $(43.47 \%)$ [12] as well as $x$ S. giganteus (47.47\%) or in wood of 4-year shoots of common osier (45.25\%) [13]. In turn, in C. flava (40.6\%), C. paniculata (38.4) and C. pilulifera (39.5\%) it is comparable to that in straw as well as Jerusalem artichoke (40.95\%), Sakhalin knotweed (40.65\%) and 1-year old shoots of common osier $(39.29 \%)$ [13]. The other species, apart from C. praecox, have slightly lower cellulose contents, but it is still markedly higher than that reported by other authors [14] in pellets from extensively managed meadows on the Noteć River $(32.85 \%, 32.75 \%)$. The lignification process in plant tissues is connected with the formation and next accumulation of lignin, which - filling the interfibril spaces in individual layers of cell walls increases their hardness, while it does not influence their tear resistance.

Mean content of lignin in cell walls in different plants is $16-32 \%$, while in the middle lamelle it may reach up to $70 \%$. Lignin has a high calorific value and its presence increases the calorific value of raw materials. It is also a natural binder enhancing fuel stability. In the analysed group of species the highest level of lignin was found in C. riparia (28.1\%), which is comparable to the contents of this component in Sakhalin knotweed (27.81\%), in barked 1-year old shoots of common osier (26.04\%) and straw of Miscanthus giganteus $(24.62 \%)$ or mature wood of white willow $(25.0 \%)$. The other sedge species were characterised by lower parameters, but still comparable to that in stems of Jerusalem artichoke (20.48\%), 4-year old shoots (20.04\%) and shoot wood (17.53\%) of common osier as well as mature wood of white poplar (Populus alba L.) (20.4\%) [13,11,]. Similar amounts of lignin (22.7-24.9\%) in genotypic switchgrass (Panicum virgatum L.) were reported [16]. Thus it may be assumed that in terms of lignin contents only C. praecox (11.9\%) differs considerably from the analysed group of sedges.

A relatively low level $(48.2-65.4 \%)$ in comparison to that in hardwood $(70-78 \%)$ [8] for the total content of polysaccharides (holocellulose) in the analysed raw materials is connected with the high amounts of extraction substances in the genus Carex (up to $23.13 \%$ ). However, it did not result in a significant reduction of calorific value of the tested biomass. Similar contents of holocellulose (approx. 52\%) in pellets from grass were reported by [14].

Extraction substances constitute a highly heterogeneous group of compounds in terms of their chemical characteristics, which common feature is their extractability with neutral organic substances and water. This group of compounds comprises essential oils, resins, fatty acids, fats, waxes, phytosterols, tannins, phenolic substances such as pigments and glycosides. Moreover, during extraction readily soluble carbohydrates such as starch, mucilage and plant gums may penetrate to solutions, along with partly soluble pectin substances, volatile organic acids, alkaloids and plant proteins. Contents of extraction substances in plant raw materials are typically $2-8 \%$, while their distribution in individual parts of plants is far from uniform. Extraction substances influence colouring, toxicity and natural stability, additionally being able to provide a characteristic smell. Waxes and fats in plants are found in slight amounts, while in certain fibrous plants they provide fibres with softness. All the tested sedge species were characterised by large amounts of substances extracted with organic solvents, being as high as $23 \%$. Also other authors [16] in four genotypic switchgrasses, i.e. alamo, GA993, GA992 and Kanlow, reported total amounts of extraction substances to be $11-13 \%$. In the analyses of plant material coming from representatives of the genus Carex no correlation was found between contents of extraction substances and calorific value of biomass. C. praecox and C. pilulifera containing $23.13 \%$ and $21.89 \%$ extraction compounds, respectively, had calorific values comparable to those of the other tested sedges, i.e. 17690 and $17030 \mathrm{~kJ} / \mathrm{kg}$. In turn, $C$. riparia containing the lowest amount $(8.07 \%)$ of extraction compounds was also characterised by the lowest calorific value of $16040 \mathrm{~kJ} / \mathrm{kg}$.

It is assumed that the average content of ash in solid non-wood biofuels ranges from 4 to $7 \%$. The analysed group of sedges (except for C. riparia) did not exceed these typical values for plant materials. Ash content in the tested sedges in case of 8 species was comparable to that found in cereal straw and sugar cane (Saccharum officinarum L.) (where it ranges from 3 to 7\%), while it was markedly lower than in rice straw, in 
which it may reach as much as $16-20 \%$. In $C$. flava and $C$. acutiformis it was below $5 \%$, i.e. it was lower than in coal (12\%) [17], straw (7.91\%) [18] or pellets from extensively managed meadows $(6.67,6.82 \%)$ [14] and it was lower than in lignite $(7.60 \%)$. In the analysed sedges its content was definitely higher than in shoots of Jerusalem artichoke (2.51\%), mature wood of pine (Pinus sp.) (0.60\%) and beech (Fagus sp.) (0.50\%) [13] and wood of Acacia cyclops A. Cunn. (2.15\%) and Acacia erioloba E. Mey (2.79\%) [19], or even in switchgrasses: alamo $(2.1 \%)$ and GA993 (2.5\%) [16].

The only species, in which a markedly higher ash content was recorded, turned out to be C. riparia. At the same time it is characterised by the lowest gross calorific value in the investigated group. Theoretically it may be assumed that the elevated content of minerals at a reduced combustion temperature should not create problems in combustion. However, a very high content $(12.3 \%)$ of minerals in C. riparia may reduce its applicability for energy use, while the low calorific value practically eliminates this raw material as biomass used for energy production. Additionally, it needs to be stressed that in C. riparia the greatest amounts of cellulose $(46.2 \%)$ and lignin $(28.1 \%)$ were detected at the lowest content of extraction substances $(8.07 \%)$. At the same time, it was C. riparia which is one of the dimensionally largest plants in the entire investigated group of species. It forms compact, frequently single-species patches in the Caricetum ripariae association, typically found over large expanses of meadows, oxbow lakes and wetlands, at the same time characterised by a longterm (up to late autumn) maintenance of green aboveground shoots, as well as high increment in biomass within a single vegetation season.

Results concerning gross calorific value were similar in all the examined sedges, except for C. riparia. These values are comparable, but still they were higher than those reported by [6] for herbage of Carex pilosa coming from beech forests. Authors conducted analyses twice - in the spring season, when this value was 18107 $\mathrm{J} / \mathrm{g}$, and in the autumn season, in which it was lower, amounting to $17884 \mathrm{~J} / \mathrm{g}$. Analyses conducted within this study on 9 sedge species were performed in autumn, thus it may be assumed that values obtained for spring herbage harvests of these sedges would be higher. In turn, results reported for C. pilosa [6] were comparable to those recorded in this study for C. riparia. Also other authors [20] on four different populations of C. pilosa confirmed high values of gross calorific values of sedges, although they were still lower than those in case of the analysed sedge species, except for C. riparia. The high gross calorific value in the genus Carex is similar to that of species A. dealbata $(19.7 \mathrm{MJ} / \mathrm{kg})$, A. glutinosa $(19.8 \mathrm{MJ} / \mathrm{kg})$, E. globulus $(19.7 \mathrm{MJ} / \mathrm{kg})$, E. saligna $(19.8$ $\mathrm{MJ} / \mathrm{kg})$, P. eridiano $(19.7 \mathrm{MJ} / \mathrm{kg})$ and $S$. mats $x$ alba $(19.6 \mathrm{MJ} / \mathrm{kg})[21]$.

Calorific value of a fuel depends on its moisture content and ash content. In this case it means that the higher the moisture and ash contents in the fuel, the lower its calorific value. It results from the above that this value changes depending on moisture content - with each percent in the increment of biomass moisture content calorific value decreases by $1.2 \%$. For example in reeds, at a moisture content of $83 \%$ calorific value is 0 [22]. Moisture content of mowed material in winter may drop to as little as $35 \%$. In case of sedges it is particularly advantageous, as in winter in many species leaves do not freeze and their harvest is facilitated due to the easier access to their habitats than in the other seasons of the year. Calorific value of the eight examined sedges was comparable to that found in Miscanthus sp. $(18.272 \mathrm{MJ} / \mathrm{kg})$, Virginia fanpetals $(18.300 \mathrm{MJ} / \mathrm{kg})$ or even willow used as an energy crop - Salix viminalis $(18.790 \mathrm{MJ} / \mathrm{kg})$ [23]. In turn, the very low value $(16040 \mathrm{~kJ} / \mathrm{kg})$ found in C. riparia was similar to that of Jerusalem artichoke $(16.653 \mathrm{MJ} / \mathrm{kg})$. The average calorific value in the dry and ash-free form for monocotyledonous plants (grasses, cereal straw and reeds) according to the Technical Specification (CEN/TS 14961:2007) is 18.4-18.5 MJ/kg. Based on these data it may be stated that the results recorded in this study identify the analysed sedge species as having calorific value slightly lower than average. In turn, the raw material coming from aboveground parts of the examined sedge species as biomass harvested for energy generation purposes may constitute good renewable fuel. It may also be assumed that it is an ecologically clean fuel with low contents of minerals. The obtained research results provide sufficient evidence to believe that the over ground parts of sedges as biomass can be used for energy purposes and provide good renewable fuel material.

\section{CONCLUSION}

Based on the conducted studies, the conclusions were described:

- Eight out of nine investigated species were characterised by comparable levels of calorific values $(18750 \mathrm{~J} / \mathrm{g}$ $19740 \mathrm{~J} / \mathrm{g}$ ).

- The lowest value of combustion heat was determined in C. riparia $(17790 \mathrm{~J} / \mathrm{g})$.

- The calorific value of all experimental sedges species with the exception of C. riparia was similar (17 310 $\mathrm{kJ} / \mathrm{kg}-18010 \mathrm{~kJ} / \mathrm{kg}$ ).

- The lowest calorific value (16 $040 \mathrm{~kJ} / \mathrm{kg})$ was found in C. riparia, while the highest $(18010 \mathrm{~kJ} / \mathrm{kg})$ - in $C$. acutiformis.

- The determined calorific value of eight examined sedges was comparable with that found in Miscantus (18 272 $\mathrm{MJ} / \mathrm{kg}$ ), Sida hermaphorodita (18 $300 \mathrm{MJ} / \mathrm{kg}$ ) and basket willow Salix viminalis (18 $790 \mathrm{MJ} / \mathrm{kg}$ ). 
- The calorific value of C. riparia was found to be close to that determined for topinambour (Helianthus tuberosus) $(16653 \mathrm{MJ} / \mathrm{kg})$.

\section{REFERENCES}

[1] TV Egorova, The Sedges (Carex L.) of Russia and Adjacent States (within the limits of the former USSR). Saint Louis: ChemicalPharmaceutical Academy; 1999.

[2] K. Virtanen and S. Valpola, Energy potential of Finnish peatlands. Geological Survey of Finland 49, $2011 ; 153-161$.

[3] H. Borkowska and R. Molas, Two extremely different crops, Salix and Sida, as sources of renewable bioenergy. Biomass Bioenergy 36,$2012 ; 234-240$

[4] H. Borkowska, R. Molas and A. Kupczyk, Virginia fanpetals (Sida hermaphrodita Rusby) cultivated on light soil: height of yield and biomass productivity. Polish Journal of Environmental Studies 18:5, 2009; 63-568.

[5] W. Harkot, M. Warda, J. Sawicki, T. Lipińska, T. Wyłupek, Z. Czarnecki and M. Kulik, Możliwości wykorzystania runi łąkowej do celów energetycznych. Lakarstwo w Polsce 10, 2007; 59-67.

[6] M. Kovačova and B. Schreiber, Aboveground biomass, energy content and phenology of Veronica officinalis L. (Scrophulariaceae) population under different canopy density of beech stand. Ekológia (Bratislava), 22(2), 2003; 119-131.

[7] M. Kuklova, J. Kukla and B. Schieber, Individual and population parameters of Carex pilosa Scop. (Cyperaceae) in four forest sites in Western Carpathians (Slovakia). Polish Journal of Ecology 53, 2005; 427-34.

[8] S. Prosiński, Chemia drewna. Warszawa: PWRiL; 1984.

[9] J. Baeza and J. Freer, Chemical Characterization of Wood and Its Components. In: Hon DNS, Shiraishi N, editors. Wood and Cellulosic Chemistry; 2000, pp. 275.

[10] R.M. Rowell, J.S. Han and S.S. Bisen, Changes in fiber properties during the growing season. In: Rowell RM, Young RA, Rowell JK, editors. Paper and Composite from Agro-based Resources. Lewis Publishers, Boca Raton, New York, London, Tokyo; 1997, p. 23-37.

[11] B. Waliszewska and W. Prądzyński, Basic chemical analysis and polymerization level of cellulose in the year-old and the multiyear shrubby willows growing by the A-2 motorway. In: Proceedings of National Symposium, Biological reactions of trees to industrial pollution. Kórnik, Poland, 2002; p. 725-732. Ed. by Siwecki R.

[12] W. Prądzyński, B. Waliszewska and S. Szczukowski, Chemical composition and heat of combustion of new Salix viminalis L. cultivars. In: Interaction of wood with various forms of energy. TU Zvolen, editors: Dubovsky J, Kudela J, 2008, p. 61-65.

[13] M. Komorowicz, H. Wróblewska and J. Pawłowski, Skład chemiczny i właściwości energetyczne biomasy z wybranych surowców odnawialnych. Ochrona Środowiska i Zasobów Naturalnych 40, 2009; 402-410.

[14] M. Grzelak, B. Waliszewska and A. Spek-Dźwigała, Wartość energetyczna peletu z łąk nadnoteckich ekstensywnie użytkowanych. Nauka Przyroda Technologie 4, 2010; 1-11.

[15] B. Waliszewska and W. Prądzyński, Chemical composition and heavy metals content in willow trees (Salix caprea L.). Annals of Warsaw Agricultural University.- SGGW 57, 2005; 279-282.

[16] J. Yan, Z. Hu, Y. Pu, E.Ch. Brummer and A.J. Ragauskas, Chemical compositions of switchgrass populations. Biomass Bioenergy 34, 2010; 48-53.

[17] R. Wichowski, Wykorzystanie słomy jako źródła energii odnawialnej w rolnictwie na przykładzie Danii. In: Seminarium krajowe. Wykorzystanie energii odnawialnej w rolnictwie. IBMER, Poznań; 1994, p. 1-10.

[18] R. Hejft, Słoma jako surowiec energetyczny. Problemy Inżynierii Rolniczej 2, 1994; 65-71.

[19] F. Munalula and M. Meincken, An evaluation of South African fuelwood with regards to calorific value and environmental impact. Biomass Bioenergy 33, 2009; 415-420.

[20] M. Kovačová, J. Kontriš and O. Kontrišová, An analysis of biomass production and energy equivalent of the Carex pilosa Scop. population in a clear felling consortium of Fagus sylvatica reserve. Ekológia (Bratislava) 18, 1999; 333-340.

[21] K. Senelwa and R.E.H. Sims, Fuel characteristics of short rotation forest biomass. Biomass Bioenergy 17, $1999 ; 127-140$.

[22] M.D. Darroch-Thompson and N. Ash, Biofuel Heating at The Farmhouse Old Moor Visitor Centre. A feasibility study for RSPB. 2003. Draft. Hunston Egineering Ltd.

[23] B. Waliszewska and I. Wiśniewska, Chemical composition and heat of combustion of selected bush willows. Annals of Warsaw Agricultural University. For. and Wood Technology. 57, 2005; 283-286. 